'Hand Development for the Performer'

Author(s): R. J. Pitcher and Jeanie J. Smith

Source: The Musical Times, Vol. 63, No. 952 (Jun. 1, 1922), p. 427

Published by: Musical Times Publications Ltd.

Stable URL: http://www.jstor.org/stable/909459

Accessed: 10-05-2016 14:10 UTC

Your use of the JSTOR archive indicates your acceptance of the Terms \& Conditions of Use, available at

http://about.jstor.org/terms

JSTOR is a not-for-profit service that helps scholars, researchers, and students discover, use, and build upon a wide range of content in a trusted digital archive. We use information technology and tools to increase productivity and facilitate new forms of scholarship. For more information about JSTOR, please contact support@jstor.org.

Musical Times Publications Ltd. is collaborating with JSTOR to digitize, preserve and extend access to The Musical Times 


\section{'QUALITY IN HYMN TUNES'}

Sir,-Your excellent digest of the lecture by Mr. H. C. Colles on Hymn-tunes is a reminder of the fact-which your readers cannot have missed-that there is now a tendency to approach this subject by methods of musical, historical, and liturgical investigation, and it is increasingly evident to all students of this branch of Church music that a wealth of material of all ages is not only available but practicable for use to-day. In spite of this it is a sad fact that the vast majority of organists and clergy have never seriously looked outside their particular book in use. The most extraordinary notions are prevalent as to the contents of the English Hymnal; for instance, that it is all Plainsong, or German Chorales, English or Welsh folksong, \&c.

After seeing in your columns a few months ago the report of a lecture where the speaker seemed possessed by some of these delusions, I was moved to look into the Hymnal and see exactly what we had found of practical use during the past fourteen years, and was really amazed at the number, variety, and, above all, the real solid musical value of the collection.

The tunes in the list (which I append) are all actually in use and known by choir and regular congregation :

Plainsong Hymn

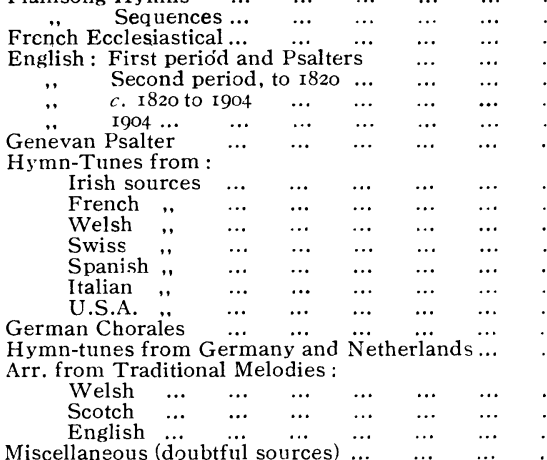

-Yours, \&c.

Stanley Road, Wellingborough.

W. CRAWLFY.

May I5, 1922.

'HAND DEVELOPMENT FOR THE PERFORMER

SIR, - 'O wad some power the giftie gie us, to see oursels as ithers see us.' Had Mr. Head never tried Mr. Matthay's admirable teaching, would he, I wonder, have venturert to express an opinion on its merits or otherwise?

Yet this is the actual position so far as the 'Techniquer' is concerned. He seems aggrieved that the 'Techniquer' makes any claim to justify its existence.

The following extract from a letter sent to the editor of one of the musical papers quite recently may be of interest to Mr. Head. The writer says :

"The result [after using a "Techniquer"] has been nothing short of marvellous. The Rotary principles advised by Matthay and his relaxation studies have now become not only possible, but a pleasure.'

Thus it would appear (as is actually the case) that the 'Techniquer' aids and abets Mr. Matthay's teachings. When all is said and done, users of the "Techniquer' are the best fitted to express an opinion as to its efficacy, and it is surely a rash statement to say that all the eminent performers and teachers who have so kindly given their testimony are 'mistaken.'

At any rate, they one and all spent some considerable time testing it before expressing an opinion.-Yours, \&c.,

$$
2 \text { I, Boundary Road, N.W.8. } \quad \text { R. J. Pitcher. }
$$$$
\text { May I I, I922. }
$$

SiR,- Your correspondent Mr. Head, whose second letter appears in your May issue, admits he has never tried or even seen a 'Techniquer,' yet he is 'impelled to contest' its claims.

My small, stiff hand had been a complete set-back to progress at the pianoforte all my life. I tried every possible device and hand gymnastics, all to no purpose; and I shall ever be grateful to Mr. Pitcher and his 'Techniquer' for the wonderful difference it has made in my case. I cannot understand a seeker after truth not giving it a trial, after reading the convincing testimony that was sent to me.Yours, \&c.,

Willowbank, Kilmacolın, Renfrewshire.

\section{THE RAFF CENTENARY}

SIR, -On May 27 it will be a hundred years since Joachim Raff first saw the light. He was one of the most famous and prolific composers of the 19th century, yet his numberless works are now most strangely and unjustly neglected. Though not a genius of the highest order (he was too eclectic for that), nevertheless many of Raff's compositions, notably the two of his eleven Symphonies, Im Walde and Leonore (both magnificent creations), chamber works (sonatas, trios, quartets, quintet, sextet, octet), pianoforte works, and others too numerous to mention are most masterly, charming, and delightful, and it is indeed an absolute shame that this splendid music is nowadays so seldom heard. Personally Raff was the most genial of men. I knew him well, having studied composition with him for half a year, for which lessons he generously declined to take any fee. He was a Swiss by birth. He died very suddenly on June $25, \mathrm{I} 882$, at the age of sixty, while occupying the distinguished post of Director of the Conservatoire at Frankfurt a/M. - Yours, \&c.,

May I6, 1922.

Algernon Ashton.

\section{THE BALLAD IN AMERICA}

SIR,-In his anxiety to lead us to despise the standard of song recitals in the United States, Mr. Kaikhosru Sorabji closes his letter (printed in your May issue) with a sentence more hasty than wise. The sneer at Charles Wakefield Cadman as a composer can be due only to ignorance of his works or failure to comprehend them. Cadman is probably the most distinguished American composer since MacDowell, and his works include orchestral, operatic. chamber, vocal, and pianoforte music. He has a truly rare gift of melody displayed in his songs, but perhaps Mr. Sorabji, being a modernist, despises anything so weak. Cadman's Pianoforte Sonata has been received as a finely-made work, full of vitality and feeling. Mr. Sorabji also has a Pianoforte Sonata, and I am waiting for a general verdict for it as good as that received by Cadman's example. With regard to Mr. Sorabji's jibe at American musical journalism, I am afraid this goes further than just musical matters. And he stresses the word ' cousins,' but he knows that white Americans and white Englishmen are just that, and that their music will draw them closer.-Yours, \&c., JOHN FiELder PORTE. 56, Mayall Road, S.E. 24. May 3, 1922.

\section{THE LEAGUE OF ARTS}

We are glad to be able to announce that the delightful entertainments given in Hyde Park last summer by the League of Arts are to be continued. On every Saturday from (and including) June 3 to July 29 performances will be given in the natural amphitheatre by the Boat-houses on the north side of the Serpentine. Tickets can be obtained, half an hour before each performance, at the Victoria and the Alexandra Gates. Two shows will be given on each Saturday, at 3.0 and 7.0 p.m., the programme being the same at each. Here is a list of works to be performed on the nine Saturdays, in order of date: Martin Shaw's Brer Rabbit, by the League of Arts; Folk-Songs and Dances, by the English Folk-Dance Society, directed by Mr. Cecil Sharp; Sea Songs and Shanties, with Dances, conducted by Mr. Geoffrey Shaw ; The Blue Bird, produced by Miss Mildred Hodges; The Masque of the Holy Grail, by Ernest Rhys, music by Vincent Thomas, produced by Mr. Alexander Payne; Fools and Fairies, adapted from A Midsummer Night's Dream by Percy A. Scholes, music by Martin Shaw, produced by Mr. E. T. Evetts's operatic class of the L.A.M. (two Saturdays); Sea Songs and Folk-Songs, with Dances, conducted by Mr. Geoffrey Shaw. If the weather is wet, the performances will be given half an hour later at Eccleston Guildhouse, I2, Berwick Street, close to Victoria Station. Information as to prices of tickets, \&c., may be obtained from the Secretary of the League, at the Guildhouse aforesaid. 